\title{
Impact of PEDDA and Cooperative Learning Approach on Students' Conception of Energy and Society in Senior Secondary School Physics in Onitsha Education Zone of Anambra State, Nigeria
}

\author{
Chukwuebuka C. Nduji Blessing Okechukwu Baridoma Kemsi \\ Department of Science Education, University of Nigeria, Nsukka, Enugu State, Nigeria
}

\begin{abstract}
The study investigated the impact of PEDDA and Cooperative Learning Approach (CLA) on students' conception of energy and society in senior secondary school physics in Onitsha Education Zone of Anambra State, Nigeria. Two research questions and one null hypothesis guided the study. The study employed quasi experimental research design. The population of the study comprised all the 6,138 SS2 physics students in 32 public secondary schools in Onitsha Education Zone of which 315 students were sampled using simple random sampling technique specifically with replacement. Four public schools or groups were used for the study. Two groups were taught using PEDDA while the other two groups taught using CLA. The instrument for data collection was Conception Test on Energy and Society (CTES) consisting of 20 multiple choice questions. The reliability coefficient of 0.82 for CTES was determined using Kudder-Richardson twenty (K-R 20) formula. Mean and standard deviation were used to answer the two research questions while ANCOVA was used to test the hypothesis. The findings revealed that male and female students' conception when taught energy and society using PEDDA and those taught using CLA is significant in favor of CLA group. Thus, the study recommended that physics teachers should adopt PEDDA so as to enhance students' conception.
\end{abstract}

Keywords: PEDDA, Cooperative Learning Approach, Gender, Energy and Society

DOI: $10.7176 / \mathrm{JEP} / 10-22-13$

Publication date: August $31^{\text {st }} 2019$

\section{Introduction}

The demand for things been made in larger quantity by machines, led to the emergence of the term 'industrial revolution'. This occurred due to average growth in population with desire of improving living standard through manufacturing and production of commercial products (Brown, 2019). Industrial revolution to some extent has influence in almost every aspect of life since its emergence. One of the influences is increase in the utility of energy since the amount of energy in a system is related to the system's ability to perform certain task called work. Thus, energy is the ability of a physical system to do work. Harper (2007) argued that in physics, quantitative property (energy) must be transferred to an object in order to perform work. Hence, when work is done, energy is used.

However, rapid increase in the use of energy in many society, have risen more than fourfold over the past three decades (United State Congress Office of Technology Assessment, 2011). Managing the use of energy is inevitable in a functional society, since energy helps people in society to control and handle environmental problems. In most developing nations, the use of energy has become crucial in; agriculture, all forms of transportation, waste collection and recycling, information technology; communication; electricity supply to homes and running of industrial machinery; heating and cooling homes; and operating domestic equipment (Anyakaoha, 2011). Anyakaoha also declined the poor state of electric energy supply in developing nations as a factor that has negative impact on the life of the people. Such negative impact include; paralyzing industrial and manufacturing machinery, and unsound economic growth of such developing nations. Negative impact of energy in the society may pose challenges on health, agricultural produce, ecosystem and many more.

The challenge of the 21th century on energy is filling the gap between energy supply and demand with clean energy, reliable and inexpensive energy (Gray, 2017). Energy supply to the society has a source in which it comes from. The sources of energy include; wind energy, geothermal energy, nuclear energy, solar energy, biomass energy, energy from coal and wood, tidal and ocean energy, energy from fossil fuel, etc (Anayakoha, 2011). Energy sources are grouped into the ones that can be replenished (renewable energy) or non-replenished (non renewable energy). Energy sources are most times referred to as energy resources. The burning of some of these energy resources generates air and water pollutants leading to acid rain, greenhouse effect, global warming and oil spillage. Energy resource pollutants are very hazardous to the environment (Abdeen, 2011), and may lead to energy crisis. The term energy crisis is referred to a great bottleneck that can occur due to shortage in supply or increasing demand, monopoly manipulation of market, industrial action by union and vandalization of pipelines (Anyakaoha, 2011). Thus, energy crisis is also a challenge to the society. For instance, increasing demand of energy and pipeline vandalization results to price hike, societal tumult and extinction of aquatic life. Therefore, in tackling some of these challenges surrounding energy uses, there comes the need of exposing students as member of the society to 
accurate conception of energy and society.

Students' conception of energy and society can be said to be idea or understanding a student possesses about the use, sources, importance and impact of energy in the society. This implies that student comes to learn a new concept (energy and society), but still have prior understanding about the concept. The students' prior understanding could be right or wrong. Thus, a student may either have scientific (sound) conception (SC) or partial understanding (PU) or alternative conception (AC) or naive conception (NC) about a concept (Orji, 2013). Scientific conception indicates that the student poses sound or right conception about the concept. Partial understanding shows learners' abandonment of his or her alternative conception. Alternative conception occurs as a result of substance-based conception that can occur due to linear explanation of a concept rather than see number of factors responsible for the concept (Alwan, 2011). Naive conception deduces failure of a student to formulate an answer. Students at this level admit that they have some exposure about the concept but could not assess or remember it (Amaechi, 2013). Students' conception of energy and society may emanate from their day-to-day activities within their environment (Weimer, 2018). For instance, students often talk about "using up" or "losing" energy (Science Learning Hub, 2018). The students conclude that since fuel can move an automobile, therefore fuel has a lot of stored energy (Fries-Gaither, 2009). Also, some students use to think of how greenhouse effect on the society looks like and how gases can fill the greenhouse (Okeke, Okeke \& Akande, 2011). This means that they conceive greenhouse effect as a building structure painted green, having different gases as its content. However, appropriate inculcation of energy and society to the students for scientific conception can be done with an effective teaching strategy.

Over the years, researchers and policy makers have been making serious effort in designing better methodologies for effective teaching strategy in science subjects, specifically physics. Such researchers efforts include, cooperative learning and problem solving (Johnson \& Johnson, 2008; Webster-Stratton \& Reid, 2008). Similarly, these researchers separate studies highlighted different types of cooperative learning and problem solving strategies. They include; Student Team Achievement Division (STAD), Pairs Check, Think-Pair-Share, Team Accelerated Instruction (TAI), Jigsaw Cooperative Learning Model and Learning Together Model. Also, Fong-Ho and Kwen-Boo (2007) in their study, 'cooperative learning: exploring its effectiveness in the physics classroom' reported that cooperative learning contributes to higher students' academic achievement in relation to physics topics. However, Fong-Ho and Kwen-Boo commented on small minority who appeared not to be motivated by the use of cooperative learning. In the same light, Hanze and Berger (2007) agreed with the above findings by reporting that increase in feelings of competence with cooperative learning are associated with students better performance in physics. With the above findings on cooperative learning, it can be said to be one of the effective teaching strategy used in science education (specifically physics). To this effect, cooperative learning will be use to compare PEDDA, this is because both are regarded as an effective teaching strategy. This is pertinent to the present study as the study seeks to determine the most effective teaching method between PEDDA and cooperative learning approach in facilitating students' conception of energy and society in senior secondary school physics. PEDDA is also one of the constructivist instructional models.

Different researchers' have made effort in eliciting a generally accepted definition of constructivism. Among these researchers are Rezaei and Katz (2002), Mandor (2004), and Eze (2005). They view constructivism from the same perspective as, 'a gradual and continuous process towards elicitation of student ideas so as to become an active participant in learning.' Also, constructivism may be seen as an approach of instruction and learning involving interactive process in social settings. This is in-line with the views of Udeogu and Njelite (2010):

Constructivism is an umbrella term for a range of theories and theorist the central thesis of which is that the learner constructs meanings or knowledge for him/her self based on his/her prior knowledge and interactions with the physical environment and that these meanings could be shared with persons or modified depending on the context. (p. 14)

Based on the above statement, constructivism can be narrowed down as an approach of instruction and learning involving interactive process in social setting. Constructivism is based on the belief that learning occurs when learners are actively involved in a process of meaning and knowledge construction as opposed to passively receiving information (Taber, 2011). This agrees with Bruner's theory on constructivism which stresses that learning is an active process in which learners construct new ideas or concepts based upon their current/past knowledge (Bruner, 1966). One of the constructivist based approaches to teaching is Prior conception, Exploration, Discussion, Dissatisfaction and Application (PEDDA).

PEDDA takes cognizance of learners' prior knowledge before learning a new concept. This is aimed at learners' achieving the required scientific conception of such concept. PEDDA model also provides students the opportunity to interact with the teacher and also among themselves in the classroom (Ekon \& Nwosu, 2016). PEDDA is a five-step conceptual change instructional model and it is from this step the acronym (PEDDA) is derived. 


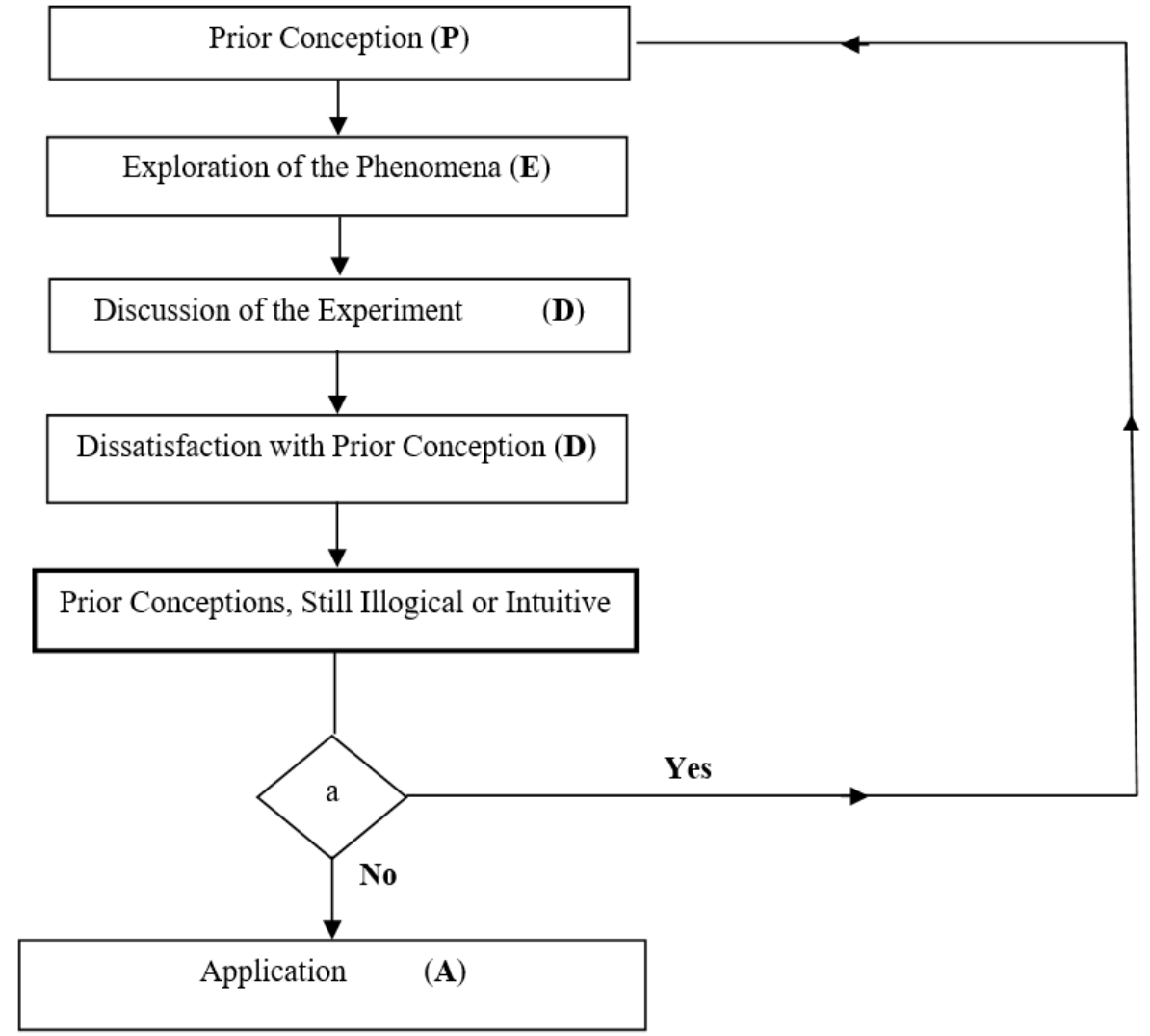

Key: a represents decision box

Fig.1. PEDDA Model by Ekon and Nwosu (2016)

The steps in the figure were further explained below

Step 1: Identification of Prior-conception (P): Here the teacher is interested on ascertaining or identifying any pre-conceived beliefs of the students, which is not in-line with the required scientific conception. The teacher achieves this by interacting with the students and asking them questions pertaining to their taught about to be learned concept. Step 2: Exploration of the phenomena (E): At this point, the teacher needs to figure out the manipulation and exploration capability of each of the student. The teacher achieves this by dividing the students into homogenous groups and give them task and materials to explore. The teacher does this with guided instruction. Step 3: Discussion of the experiment: This comes after exploration of phenomena whereby the teacher calls the students together from there different groups. The aim is to discuss their observation and results based on the performed task/activity. Question and answer should be allowed at this point. Step 4: Dissatisfaction with priorconception: Here the teacher could ascertain through discussion, questioning and answering, if students still holds on their pre-conceived beliefs that were brought into classroom. If the student still holds unto their prior-conception, the decision is 'Yes' and the teachers moves back to step 2. However, if the student believes and accepts the new concepts and rejects their prior-conceptions, the decision is 'NO'. The teacher advances to the next step (5). Step 5: Application (A): The students can discuss concept that is learnt confidently with facts and figures. This concept that is learnt can be applied outside the classroom room setting, which shows knowledge gained. Thus, that knowledge can be applied to the immediate society to enhance development.

However, studies conducted using PEDDA shows that PEDDA enhances students' conceptual change. These studies include but are not limited to; utilizing PEDDA as an effective teaching strategy for better cognitive achievement and interest in biology (Ekon \& Nwosu, 2016); It's all in the brain: of gender and achievement in science and technology education (Nzewi, 2015); secondary school students' assessment of innovative teaching strategy in enhancing achievement in physics and mathematics (Agummuoh \& Ifeanacho, 2013). However, all these studies were conducted by comparing PEDDA with traditional (or conventional) method of teaching, whereas the present study will be conducted by comparing PEDDA with another constructivist approach which is cooperative learning to ascertain male and female (i.e. gender) students conception of energy and society in senior secondary school physics.

Gender may influence the use of PEDDA as an effective teaching approach in facilitating students' conception of energy and society. Gender is a dimension of social organization which shapes how people interact with others and how people behave or act and think about themselves (Zudonu, 2013). Gender may be the characteristics upon which people define male or female. Though, there has been no consistent report on the influence of gender on 
students' conception of physics concept. Findings by (Arigbadu \& Miji, 2004; Bilesanmi-Awoderu, 2006) showed that there are no longer distinguishing differences in the cognitive effective and psychomotor skills of students in respect to gender. Also another study by Agomuoh cited in Nzewi (2015) revealed that when male and female students were taught physics concepts using the Prior knowledge, Exploration Discussion Dissatisfaction with prior knowledge and Application method (PEDDA), and The Learning Cycle (TLC) Constructivist model, both methods facilitate conceptual change of both male and female students from alternative conception to accepted scientific conception. It implies that PEDDA is effective in changing students' conception and it is gender friendly.

From the discussion, it can seen that PEDDA as an instructional model have not been compared with any other instructional model specifically from the same pedestal of constructivist instructional model, rather traditional method has been used. To this end, the present study is geared towards comparing between cooperative learning approach and PEDDA so as to infer which among the two approaches is more effective. Also, it has not been objectively established how gender friendly PEDDA is on students' conception of energy and society. Thus, this necessitated the present study.

\section{Research Questions}

In this study, answers were provided to the following questions;

1. What are the mean scores of students' conception when taught energy and society using PEDDA and those taught using the Cooperative Learning Approach (CLA)?

2. What are the mean scores of male and female students' conception when taught energy and society using PEDDA and those taught using the Cooperative Learning Approach (CLA)?

\section{Research Hypothesis}

The null hypothesis guided the study. The hypothesis was tested at 0.05 level of significance.

HO1: There is no significant difference in the mean score of male and female students' conception when taught energy and society using PEDDA and those taught using the Cooperative Learning Approach (CLA).

\section{Method}

The researchers employed quasi experimental research design, specifically factorial design of 2 by 2 factors. This study was carried out in Onitsha Education Zone of Anambra State. The population of the study comprised all the 6,138 SS2 physics students in 32 public secondary schools in Onitsha Education Zone of Anambra State. Four public schools (or groups) were selected from schools in the study area using simple random sampling technique specifically with replacement. Two groups were taught using PEDDA representing 163 students while the other two groups taught using CLA representing 152 students. Both groups comprised of 315 SS2 students used for the study. An instrument titled Conception Test on Energy and Society (CTES) consisting of 20 standardized multiple choice questions constitute the instrument used for the study. CTES was adapted from New Secondary School Physics Textbook exercises using test blueprint to ensure content coverage. The instrument was face validated by four experts (i.e. one physics educator, one from physics and astronomy, two from measurement and evaluation) all in University of Nigeria, Nsukka. The reliability of the instrument was determined using Kudder-Richardson twenty (K-R 20) formula. The choice of this reliability is because the instrument is dichotomously scored items (multiple choice tests). With the formula, a reliability index of 0.82 was calculated.

\subsection{Treatment Procedure}

The two groups were equal in all areas, both in content, objective and instructional approaches. CTES was used to pretest both PEDDA and CLA group at the beginning. Students in PEDDA group received class on energy and society using PEDDA strategy. The strategy involves prior conception, exploration of the phenomenon, discussion of the experiment, dissatisfaction and application, while CLA group were taught in pairs or small group and allowed to work together on a given task. Four weeks were used for training sessions of the groups where each session lasted for $45 \mathrm{mins}$, two times in a week. The same CTES was re-administered at the end of the training session to both groups to determine students' conception of energy and society using PEDDA as an effective teaching approach. Mean and standard deviation were used to answer the two research questions while ANCOVA was used to test the hypothesis.

\section{Results}

Research Question 1: What are the mean scores of students' conception when taught energy and society using PEDDA and those taught using the Cooperative Learning Approach (CLA)? 
Table 1: Mean and standard deviation of students' conception when taught energy and society using PEDDA and those taught using the cooperative learning approach

\begin{tabular}{lllllll}
\hline Methods & N & Pretest Mean & Std. Dev. & Posttest Mean & Std. Dev & Mean Gain \\
\hline PEDDA & 163 & 13.25 & 1.262 & 18.04 & 1.494 & 4.79 \\
CLA & 152 & 13.34 & 1.196 & 15.77 & 1.982 & 3.99 \\
\hline
\end{tabular}

Table 1 showed the pretest mean and standard deviation score for PEDDA group are 13.25 and 1.262, while the posttest mean and standard deviation scores for PEDDA group are 18.04 and 1.494 with mean gain of 4.79. But students who were taught energy and society using CLA had pretest mean and standard deviation of 13.34 and 1.196, while the posttest mean and standard deviation for CLA are 15.77 and 1.982 with mean gain of 3.99. This indicates that students who were taught energy and society using PEDDA approach had higher conception than those taught using cooperative approach. This means that PEDDA is more superior over CLA in promoting students' conception of energy and society as judged by the mean gain.

Research Question 2: What is the mean score of male and female students' conception when taught energy and society using PEDDA and those taught using the cooperative learning approach?

Table 2: Mean and standard deviation of male and female students' conception when taught energy and society using PEDDA and those taught using the cooperative approach

\begin{tabular}{lllccccc}
\hline Method & Gender & $\mathbf{N}$ & $\begin{array}{c}\text { Pretest } \\
\text { Mean }\end{array}$ & Std. Dev. & $\begin{array}{c}\text { Posttest } \\
\text { Mean }\end{array}$ & Std. Dev. & $\begin{array}{c}\text { Mean } \\
\text { Gain }\end{array}$ \\
\hline PEDDA & Male & 88 & 13.09 & 1.301 & 18.11 & 1.608 & 5.02 \\
& Female & 75 & 13.43 & 1.199 & 17.95 & 1.355 & 4.52 \\
CLA & Male & 78 & 13.41 & 1.200 & 16.72 & 2.119 & 3.31 \\
& Female & 74 & 13.26 & 1.194 & 14.77 & 1.211 & 1.51 \\
\hline
\end{tabular}

Data presented in table 2 showed that the pretest mean and standard deviation scores of male students who were taught energy and society using PEDDA approach are 13.09 and 1.301, while that of female students are 13.43 and 1.199. Also, the pretest mean and standard deviation scores of male students in CLA group are 13.41 and 1.200, while that of female students are 13.26 and 1.194. This means that male and female students in PEDDA and CLA groups have almost the same energy and society conception mean baseline before experimental treatment.

However, the posttest mean and standard deviation scores for male in PEDDA group are 18.11 and 1.608 with mean gain of 5.02, while that of female in the same group are 17.95 and 1.355 with mean gain of 4.52. Also, the posttest mean and standard deviation for male in CLA group are 16.72 and 2.119 with mean gain of 3.31, while that of female students in the same group are 14.77 and 1.211 with mean gain of 1.51 . This implies that male and female students in PEDDA group had almost the same mean score. Also, male and female students in the CLA group differ in mean scores. This implies that PEDDA is gender friendly, unlike CLA. Students who were taught energy and society using PEDDA approach had higher conception than those taught using cooperative approach. Nevertheless, the supportive hypotheses will be tested to ascertain the difference.

Hypotheses 2: There is no significant difference in the mean score of male and female students' conception when taught energy and society using PEDDA and those taught using the CLA.

Table 3: Analysis of covariance (ANCOVA) of the effect of PEDDA and CLA on male and female students' conception of energy and society in senior secondary school physics

\begin{tabular}{lccccc}
\hline Source & Type III Sum of Squares & df & Mean Square & F & Sig. \\
\hline Corrected Model & $579.240^{\mathrm{a}}$ & 4 & 144.810 & 57.279 & .000 \\
Intercept & 481.439 & 1 & 481.439 & 190.430 & .000 \\
Pretest & 29.808 & 1 & 29.808 & 11.790 & .001 \\
Method & 416.025 & 1 & 416.025 & 164.556 & .000 \\
Gender & 91.352 & 1 & 91.352 & 36.134 & .000 \\
Method * Gender & 53.291 & 1 & 53.291 & 21.079 & .000 \\
Error & 783.732 & 310 & 2.528 & & \\
Total & 91787.000 & 315 & & & \\
Corrected Total & 1362.971 & 314 & & & \\
\hline
\end{tabular}

a. R Squared $=.425$ (Adjusted R Squared $=.418$ )

Table 3 shows that the calculated value of F (21.079) for the effect of PEDDA and CLA on male and female students' conception of energy and society in senior secondary school physics had an associated probability value of 0.000 . Since the probability value of 0.000 is less than the 0.05 level of significance, the null hypothesis was rejected. This implies that there is significant difference in the mean score of male and female students' conception when taught energy and society using PEDDA and those taught using CLA in favor of CLA group with high mean difference between male and female students. 


\subsection{Discussion of Findings}

The finding of the study in table 1 revealed that students who were taught energy and society using PEDDA approach had higher conception than those taught using cooperative approach. This suggests that PEDDA is more superior over CLA in promoting students' conception of energy and society. The significance in students' conception of energy and society due to use of constructive instructional model PEDDA, may be as a result of active involvement of students in the class that is; students' centeredness, interaction, exploration and manipulation of different activities they engage in. The finding of this study agrees with the finding of Duit as cited in Ekon and Nwosu (2016) who revealed that constructive based instructional methods (PEDDA) provides useful model for conceptual change than conventional method. Similarly, Udeogu and Njelita (2010) whose finding indicates that constructivist based instructional method is more superior to expository method on students' conceptual change of some difficult concepts in chemistry, is in agreement with the present finding.

Lastly, the result of this study as shown in table $2 \& 3$ revealed that PEDDA is gender friendly, unlike CLA. Also, there is significant difference in the mean score of male and female students' conception when taught energy and society using PEDDA and those taught using CLA in favor of CLA group. This implies that cooperative learning approach is gender biased while PEDDA is gender friendly instructional approach on students' conception of energy and society. This is in alignment with the finding of Afolabi and Akinyemi (2009) who revealed that the physics students with low ability level taught with constructive based method performed significantly better than those taught with conventional method.

\section{Conclusion}

From the results obtained in the study, the researchers concluded that PEDDA used in teaching physics students have higher impact on students' conception of energy and society than cooperative learning approach. However, PEDDA also is gender friendly unlike cooperative learning approach.

\section{Recommendations}

Based on the findings of this study, the researchers recommended that

1. Physics teachers should adopt PEDDA so as to enhance students' conception since PEDDA is gender friendly. This will help mitigate gender stereotype among students.

2. Challenging instructional materials or classroom activities should be unveiled to the students so as to enhance their conception about a concept.

3. Teachers should provide platform for students to express themselves in different ways.

\section{References}

Abdeen, M.O. (2011). Energy and environment: applications and sustainable development. Energy research institute (ERI), Nottingham, United Kingdom. British Journal of Environment \& Climate Change, 1(4), 118158.

Agummuoh, P.C. \& Ifeanacho, A.O. (2013). Secondary school students' assessment of innovative teaching strategy in enhancing achievement in physics and mathematics. Journal of Educational and Social Research, $3(8), 121-128$.

Alwan, A.A. (2011). Conception of heat and temperature among physics students. Procedia Social and Behavioural Science, 12, 600-614. Retrieved July 15 ${ }^{\text {th }}$, 2019, from www.sciencedirect.com

Amaechi, C.C. (2013). Effects of the learning cycle model on students understanding of physics concepts. (Unpublished master thesis). University of Nigeria, Nsukka, Enugu State, Nigeria.

Anyakoha, M.W. (2011). New School Physics (4 ${ }^{\text {th }}$ ed.). Enugu: Africana First Publishers.

Arigbadu, A.A. \& Miji, A. (2004). Is gender a factor in mathematics performance among Nigeria Pre-service teachers? $\quad$ Retrieved $\quad$ September $\quad 2^{\text {nd }}, \quad$ from www.academia.edu//./\&6978/Is_gender_a_factor_in_mathematics_performance_among_Nigeria.

Bilesanmi-Awoderu, J.B., (2006). Effect of computer assisted instruction and simulation/games on the academic achievement of secondary school students in biology. Sokoto Educational Review, 8(1), 49-60.

Brown, C. S. (2019). The industrial revolution. Retrieved April 2 $2^{\text {nd }}$ 2019, from https://www.khanacademy.org/partern-content/big-history-project/acceleration/a/the-industrial-revolution.

Bruner, J. (1966). Toward a Theory of Instruction. Cambridge, MA: Harvard University Press.

Ekon, E.E. \& Nwosu, A.A. (2016). Utilizing PEDDA as an effective teaching strategy for better cognitive achievement and interest in biology. $5^{\text {th }}$ Annual Conference Proceedings of Science Teachers' Association of Nigeria, 410-418.

Eze, J.U. (2005). Science and Teaching in Secondary Schools: Capacity Building Strategy for Enhancement. Journal of World Council for Curriculum and Instruction, Nigerian Chapter Forum, 5(2), 265-271.

Fong-Ho, F. \& Kwen-Boo, H. (2007). Cooperative learning: exploring its effectiveness in the physics classroom. Asia-Pacific Forum on Science Learning and Teaching, 8(2), 22-34. 
Fries-Gaither, J. (2009). Common misconception about heat and insulation. National Science Education Standards. Retrieved from September 27 $7^{\text {th }}$, 2018, www.beyondpenguis.ehe.osu.edu/issue/keeping-warm/commonmisconception-about-heat-and-instulation.

Gray, R. (2017). The biggest energy challenge facing humanity. Retrieved from www.bbc.com/future/story/20170313-the-biggest-energy-challenges-facing-humanity

Hanze, M. \& Berger, R. (2007). Cooperative learning, motivational effects and student characteristics: an experimental study comparing cooperative learning and direct instruction in $12^{\text {th }}$ grade physics classes. Retrieved from www.elsevier.com/locate/learninginstruction.

Harper, D. (2011). Energy. Online etymology dictionary. Retrieved from www.etymonline.com

Johnson, R.T. \& Johnson, D.W. (2008). Active learning: cooperation in the classroom. The Annual Report of Educational Psychology in Japan, 47, 29-30.

Mandor, A.K. (2004). Effect of constructivist-based istructional models on acquisition of science process skill among junior secondary students. (Unpublished masters' thesis). University of Nigeria Nsukka, Enugu State, Nigeria.

Nzewi, U.M. (2015). It's all in the brain: of gender and achievement in science and technology education. 52 Inaugural Lecture, University of Nigeria Nsukka. Retrieved March $6^{\text {th }}, 2019$, from www.unn.edu.ng/wpcontent/uploads/2015/09/52nd-Lecture1.pdf.

Okeke, P.N., Okeke, F.N. \& Akande, S.F. (2011). Senior secondary school physics. Macmillan Lagos: Nigeria publishers limited.

Orji, E.I. (2013). Relative effect of cognitive conflict instructional strategy and conceptual change pedagogy on students' conceptual change and attention in temperature and heat. (Unpublished masters' thesis). University of Nigeria, Nsukka, Enugu State, Nigeria.

Rezaei, A.R. \& Katz, L. (2002). Using computer assisted instruction to compare the inventive model and the radical constructivist approach to teaching physics. Journal of Science Education and Technology, 11(4), 367-380.

Sciencelearninghub. (2018). Alternative conception about energy. Retrieved September 25 ${ }^{\text {th }}$, 2018, from www.sciencelearn.org.nz/resources/1756-alternative-conceptions-about-energy.

Taber, K. S. (2011). Constructivism as educational theory: Contingency in learning, and optimally guided instruction. In J. Hassaskhah (Ed.), Educational Theory (pp. 39-61). New York: Nova. Retrieved February $12^{\text {th }}, 2019$, from https://camtools.cam.ac.uk/wiki/eclipse/Constructivism.html.

Udeogu, M.E. \& Njelita, C.B. (2010). Effect of constructivist- based instructional model on students' conceptual change and retention on some difficult concepts in chemistry. An International Multi-Disciplinary Journal, Ethiopia, 4(2), 219-229.

United State Congress Office of Technology Assessment (2011). Energy in developing countries. Washington, DC: U.S. Government Printing Office, OTA-E-486.

Webster-Stratton, C.W. \& Reid, M.J. (2008). Strengthening social and emotional competence in young childrenthe foundation for early school readiness and success: incredible years classroom social skills and problem solving. Journal Infants \& Young Children, 17(2), 96-113.

Weimer, M. (2018). Students' conception of teaching and learning. Retrieved September 9 ${ }^{\text {th }}$, 2018, from http://www.facultyfocus.com

Zudonu, O.C. (2013). The effect of laboratory instructional methods on students' conceptual change, achievement and attitude to some chemistry concepts at senior secondary school level. (Unpublished masters' thesis). University of Nigeria, Nsukka, Enugu State, Nigeria. 